\title{
Socio economic and Psychological Profile of Members of Self Help Groups in Ramanagara District of Karnataka, India
}

\author{
K. Asha, D. Nanjappa, M.B. Shanabhoga* and Shivani Dechamma \\ Department of Agricultural Extension, University of Agricultural Sciences, GKVK, \\ Bengaluru-65, Karnataka, India \\ *Corresponding author
}

\section{Keywords}

Self-help group, Women members, Socio- economic profile

Article Info

Accepted:

24 August 2018

Available Online:

10 September 2018

\section{A B S T R A C T}

SHGs are novel and innovative organizational setup in India for the women upliftment and welfare. Women in India are given chance to join any one of the SHGs for training and development, so as to be prospective entrepreneur and skilled worker. The study was conducted in Ramanagara district of Karnataka. Channapatna and Magaditaluks were purposively selected based on highest and lowest number of women SHGs respectively. Hence, eight women groups were selected. In each of the SHG 15 members were there inclusive of president and secretary constituting a sample size of 120 for the study. The Ex-post-facto Research Design has been adopted in the present study. With regard to personal variables a majority $(63.33 \%)$ of members in women SHG belonged to middle age, nearly half of $(41.70 \%)$ the members were illiterates, majority $(89.20 \%)$ of members were married, majority $(58.30 \%)$ of members belonged to small family and more than half $(55.80 \%)$ of members belonged to nuclear family. With regard to socio-economic characteristics a majority $(79.17 \%)$ of women SHG members belonged to low family annual income without SHG income. More than one third (39.18\%) of the respondents belonged to medium level of extension participation, about one third $(39.67 \%)$ of the respondents belonged to low level of mass media exposure. With respect to the purpose of visit to the nearest town 'related to SHG activities' ranked first. With regard to psychological characteristics little more than one third (35.87\%) of the women SHG members belonged to medium level of risk willingness whereas 41.67 per cent of members belonged to medium level of achievement motivation, further, 47.50 per cent of members belonged to medium level of management orientation and 40.83 per cent of members belonged to medium level of deferred gratification.

\section{Introduction}

Poverty, unemployment, poor health, lack of education etc., are the major problems in many developing nations. The growing problem in India has prompted the economic planners to come up with various programmes that can help in combating it. Self Help Groups are the avenues to enable the poor to participate in the process of development. The concept of SHGs gained significance, especially after 1976 when Prof. Mohammed Yunus of Bangladesh began experimenting with micro-credit and women SHGs. The 
strategy made a silent revolution in Bangladesh in poverty eradication by empowering the poor women. SHGs are small informal groups created for the purpose of enabling members to get economic benefit out of mutual help, solidarity and joint responsibility.

The benefits include mobilization of savings, credit facilities and pursuit of group enterprise activities. The group based-approach not only enables the poor to accumulate capital by way of small savings but also help them to have access to formal credit facilities. In general, the SHGs created were implemented to reach the poor effectively, the women in particular and help them to obtain easy access to facilities like savings and credit in the long run in alleviating poverty by empowering them.

The progress of any SHGs depends on the participation of its members in different activities, and their active involvement in the activities of programs of SHGs and also the activities organized by the other organizations. Performance is the criteria by which the effectiveness of a self-help group is measured.

\section{Materials and Methods}

The study was conducted in Ramanagara district of Karnataka state during the year 2014-15. Channapatna and Magaditaluks were purposively selected based on highest and lowest number of women SHGs respectively. From each taluk, two villages were randomly selected, namely Krishnapura and Agrahara Varagerahalli from Channapatnataluk, Madabaal and Shambudevanahalli from Magaditaluk. The criteria followed to select women SHG was that the group should have been completed minimum of five year of its function. Two women Self Help Groups were selected from each village. Hence, eight women groups were selected. In each of the SHG 15 members were there inclusive of president and secretary constituting a sample size of 120 for the study. Ex-post facto research design was employed. A structured schedule was used to collect the data from the respondents by employing personal interview method. The data were analyzed with the help of statistical tools like frequency, percentage, mean, standard deviation and chi square.

\section{Results and Discussion}

\section{Personal, socio-economic and psychological characteristics of women SHG members}

Age

It could be observed from the Table 1 that, majority $(63.33 \%)$ of members in women SHG belonged to middle age, 20 per cent of the members belonged to old age and 16.70 per cent members belonged to young age.

Taking up the responsibility to run the family, incentives available from SHG like access to loan and information might be the reasons for predominance of middle aged respondents. The findings are in line with the findings of Chethana (2005) and Sangappa (2012).

\section{Education}

It could be evident from the Table 2 that, about 41.70 per cent of the members in women SHG were illiterate, 31.70 per cent, 20.00 per cent and 6.60 per cent members fall under low, medium and high education categories respectively.

This situation might have evolved due to low financial position of the family, poor education facilities during their childhood days, schools located in faraway places, negligence of elders for children's education and labour requirement in their own farm. The findings are in line with the findings of Rangi et al., (2002) and Arunkumar (2004). 


\section{Marital status}

It could be evident from Table 3 that majority $(89.20 \%)$ of women SHG members are married, 9.10 per cent are widows and only 1.70 per cent was un married. The reason might be that SHG is a long-term activity; women tend to leave the villages once they get married. SHG is a long-term activity and leaving the group either for marriage or any other reason at any stage of SGH would hamper its progress. This could be the reason why majority of the members were from married category. The findings are in line with the findings of Prasad (1998) and Arunkumar (2004).

\section{Family size}

It could be observed from the Table 4 that, majority $(58.30 \%)$ of women SHG members belonged to small family size, 23.40 per cent and 18.30 per cent of women SHG members fallen under big and medium families, respectively.

This might be due to their awareness regarding the increased cost of living and difficulties in maintenance of big family and they might have found it beneficial to have small families to lead a better and comfortable life. The findings are in contrast with the findings of Sangappa (2012).

\section{Family type}

It is apparent from Table 5 that 55.80 per cent of women SHG members belonged to nuclear family and 44.20 per cent of women SHG members belonged to joint family. The predominance of nuclear family due to realization of the advantages of nuclear families in terms of running the family, less responsibilities, privacy etc. The findings of the present study are in line with Arunkumar (2004) and Bharathi (2005).

\section{Annual income}

It was evident from Table 6 that majority (79.17\%) of women SHG members belonged to low family annual income without SHG income followed by medium $(12.50 \%)$ and high $(8.33 \%)$ categories respectively.

Whereas, in case of annual income from family annual income without SHG income and family annual income including SHG income 38.33 per cent of women SHG members belonged to low income category followed by high $(33.33 \%)$ and medium (28.34\%) categories respectively. Low income of members might be due to poverty and small holdings of dry land.

Whereas, annual income has been increased from 8.33 per cent in family annual income without SHG income to 33.33 per cent in family annual income including SHG income with high annual income categories.

Similarly with the medium categories of both the types of income measured there was change from 12.50 per cent to 28.34 per cent. This might be due to the intervention of SHG.

It was evident from Table 7 that 43.33 per cent of the members belonged to medium category of annual income from SHGs followed by low $(35.00 \%)$ and high $(21.67 \%)$ categories respectively. Here we can notice that, nearly two third of the respondents belonged to medium to high annual income from SHGs category.

This might be due to the income generating activities taken up by the members of SHG. Further, it is noticed that due to SHG activities members of SHG were getting an average income ranging from Rs. 17315 to Rs.33860 is an important phenomenon. The results were in line with Banerjee (2002) and Purushotham et al., (2010). 


\section{Details of SHGs selected for the study}

\begin{tabular}{|c|c|c|c|c|}
\hline Name of the village & $\begin{array}{c}\text { No. of } \\
\text { SHGs }\end{array}$ & Name of the SHG & $\begin{array}{c}\text { Year of } \\
\text { start }\end{array}$ & $\begin{array}{c}\text { No. respondents } \\
\text { selected }\end{array}$ \\
\hline Krishnapura & 2 & $\begin{array}{c}\text { Chowdeshwari } \\
\text { Bhuvaneshwari }\end{array}$ & 2001 & 2001 \\
\hline A graharaVaragerahalli & 2 & Shakthimata & 2001 & 15 \\
& & Bhagirathi & 2005 & 15 \\
\hline Madabaal & 2 & Mahadevamma & 2003 & 15 \\
\hline Shambudevanahalli & \multirow{2}{*}{2} & Bhuvaneshwari & 2001 & 15 \\
& & Bariyamma & 2003 & 15 \\
\hline & & Pattaladamma & 2003 & 15 \\
\hline
\end{tabular}

Table.1 Distribution of respondents according to their age

\begin{tabular}{|c|c|c|c|}
\hline SI. No. & Category & Frequency & Per cent \\
\hline 1. & Young (18 to 35) & 20 & 16.70 \\
\hline 2. & Middle (36 to 50) & 76 & 63.30 \\
\hline 3. & Old (Above 51) & 24 & 20.00 \\
\hline & Total & 120 & 100.00 \\
\hline
\end{tabular}

$(\mathrm{n}=120)$

Table.2 Distribution of respondents according to their education

\begin{tabular}{|c|c|c|c|}
\hline SI. No. & Category & Frequency & Per cent \\
\hline 1. & Illiterate (no formal education) & 50 & 41.70 \\
\hline 2. & Low (Read or write, primary and middle) & 38 & 31.70 \\
\hline 3. & Medium (High school and SSLC) & 24 & 20.00 \\
\hline 4. & High (PUC and Degree) & 08 & 06.60 \\
\hline & Total & 120 & 100.00 \\
\hline
\end{tabular}

Table.3 Distribution of respondents according to their marital status

\begin{tabular}{|c|c|c|c|}
\hline S. No. & Category & Frequency & Per cent \\
\hline 1. & Married & 107 & 89.20 \\
\hline 2. & Unmarried & 2 & 01.70 \\
\hline 3. & Widow & 11 & 09.10 \\
\hline & Total & 120 & 100.00 \\
\hline
\end{tabular}

$(\mathrm{n}=120)$ 
Table.4 Distribution of respondents according to their family size

\begin{tabular}{|c|c|c|c|}
\hline SI. No. & Category & Frequency & Per cent \\
\hline 1. & Small (1-4) & 70 & 58.30 \\
\hline 2. & Medium (5-6) & 22 & 18.30 \\
\hline 3. & Big (7 and above) & 28 & 23.40 \\
\hline & Total & 120 & 100.00 \\
\hline
\end{tabular}

$(n=120)$

Table.5 Distribution of respondents according to their family type

\begin{tabular}{|c|c|c|c|}
\hline SI. No. & Category & Frequency & Per cent \\
\hline 1. & Nuclear & 67 & 55.80 \\
\hline 2. & Joint & 53 & 44.20 \\
\hline & Total & 120 & 100.00 \\
\hline
\end{tabular}

$(n=120)$

Table.6 Distribution of respondents according to their annual income

\begin{tabular}{|c|c|c|c|c|c|}
\hline \multicolumn{2}{|c|}{ Category } & \multicolumn{3}{|c|}{ Family } & \multicolumn{2}{c|}{ SHG } \\
\cline { 2 - 6 } No. & & frequency & Per cent & frequency & Per cent \\
\hline 1. & Low $(\leq 40,000)$ & 95 & 79.17 & 108 & 90.00 \\
\hline 2. & Medium(40,000 to 60,000$)$ & 15 & 12.50 & 9 & 07.50 \\
\hline 3. & High $(>60,000)$ & 10 & 08.33 & 3 & 02.50 \\
\hline & Total & 120 & 100.00 & 120 & 100.00 \\
\hline
\end{tabular}

Table.7 Distribution of respondents according to their annual income from SHGs

\begin{tabular}{|c|c|c|c|c|}
\hline SI. No. & Category & Frequency & Per cent & \\
\hline 1. & Low $(<17315)$ & 42 & 35.00 & Mean $=25588$ \\
\hline 2. & Medium(17315-33860) & 52 & 43.33 & \\
\hline 3. & High(> 33860) & 26 & 21.67 & S.D. $=16544$ \\
\hline & Total & 120 & 100.00 & \\
\hline
\end{tabular}

Table.8 Distribution of respondents according to their extension participation

\begin{tabular}{|c|c|c|c|c|}
\hline SI. No. & Category & Frequency & Per cent & \\
\hline 1. & Low $(<1.437)$ & 42 & 35.00 & Mean $=$ \\
\hline 2. & Medium(1.437-3.096) & 47 & 39.18 & 2.267 \\
\hline 3. & High(> 3.096) & 31 & 25.82 & S.D. $=$ \\
\hline & Total & 120 & 100.00 & 1.659 \\
\hline
\end{tabular}


Table.9 Distribution of respondents according to their social participation

\begin{tabular}{|c|c|c|c|c|}
\hline SI. No. & Category & Frequency & Per cent & \\
\hline 1. & Low $(<0.059)$ & 71 & 59.16 & Mean $=$ \\
\hline 2. & Medium $(0.059-3.757)$ & 27 & 22.50 & 1.908 \\
\hline 3. & High $(>3.757)$ & 22 & 18.34 & S.D. $=3.699$ \\
\hline & Total & 120 & 100.00 & \\
\hline
\end{tabular}

Table.10 Distribution of respondents according to their mass media exposure

\begin{tabular}{|c|c|c|c|c|}
\hline SI. No. & Category & Frequency & Per cent & \\
\hline 1. & Low $(<2.7)$ & 47 & 39.67 & Mean $=4$ \\
\hline 2. & Medium $(2.7-5.3)$ & 45 & 37.50 & \\
\hline 3. & High $(>5.3)$ & 28 & 23.33 & S.D. $=2.6$ \\
\hline & Total & 120 & 100.00 & \\
\hline
\end{tabular}

$(n=120)$

Table.11 (a) Distribution of respondents according to their cosmopoliteness (no. of visits)

\begin{tabular}{|c|c|c|c|c|}
\hline SI. No. & Category & Frequency & Per cent & \\
\hline 1. & Low $(<2.65)$ & 35 & 29.17 & Mean $=3.15$ \\
\hline 2. & Medium $(2.65-3.65)$ & 42 & 35.00 & \\
\hline 3. & High $(>3.65)$ & 43 & 35.83 & S.D. $=1.00$ \\
\hline & Total & 120 & 100.00 & \\
\hline
\end{tabular}

Table.11 (b) Distribution of respondents according to their purpose of visit

\begin{tabular}{|c|c|c|c|c|}
\hline SI. No. & Category & Frequency & Per cent & Rank \\
\hline 1. & Related to SHG & 118 & 98.33 & I \\
\hline 2. & Personal / Domestic & 92 & 76.67 & II \\
\hline 3. & Entertainment & 1 & 00.83 & III \\
\hline
\end{tabular}

Multiple responses obtained

$(n=120)$

Table.12 Distribution of respondents according to their risk willingness

\begin{tabular}{|c|c|c|c|c|}
\hline SI. No. & Category & Frequency & Per cent & \\
\hline 1. & Low $(<27.29)$ & 39 & 32.50 & Mean $=29$ \\
\hline 2. & Medium $(27.29-30.77)$ & 43 & 35.83 & \\
\hline 3. & High $(>30.77)$ & 38 & 31.67 & S.D. $=3.5$ \\
\hline & Total & 120 & 100.00 & \\
\hline
\end{tabular}


Table.13 Distribution of respondents according to their achievement motivation

\begin{tabular}{|c|c|c|c|c|}
\hline SI. No. & Category & Frequency & Per cent & \\
\hline 1. & Low $(<16.13)$ & 39 & 32.50 & Mean $=$ \\
\hline 2. & Medium $(16.13-18.22)$ & 50 & 41.67 & 17.18 \\
\hline 3. & High $(>18.22)$ & 31 & 25.83 & S.D. $=2.09$ \\
\hline & Total & 120 & 100.00 & \\
\hline
\end{tabular}

$(n=120)$

Table.14 Distribution of respondents according to their management orientation

\begin{tabular}{|c|c|c|c|c|}
\hline S. No. & Category & Frequency & Per cent & \\
\hline 1. & Low $(<40.49)$ & 35 & 29.17 & Mean $=$ \\
\hline 2. & Medium $(40.49-45.57)$ & 57 & 47.50 & 43.03 \\
\hline 3. & High $(>45.57)$ & 28 & 23.33 & S.D. $=$ \\
\hline & Total & 120 & 100.00 & 5.082 \\
\hline
\end{tabular}

$(\mathrm{n}=120)$

Table.15 Distribution of respondents according to their deferred gratification

\begin{tabular}{|c|c|c|c|c|}
\hline SI. No. & Category & Frequency & Per cent & \\
\hline 1. & Low $(<31.55)$ & 42 & 35.00 & Mean $=$ \\
\hline 2. & Medium $(31.55-36.40)$ & 49 & 40.83 & 33.98 \\
\hline 3. & High $(>36.40)$ & 29 & 24.17 & S.D. $=4.852$ \\
\hline & Total & 120 & 100.00 & \\
\hline
\end{tabular}

$(n=120)$

\section{Extension participation}

The results in Table 8 brought to the focus that 39.18 per cent of the respondents belonged to medium level followed by low $(35.00 \%)$ and high $(25.82 \%)$ level of extension participation. The reason for medium to low extension participation is due to lack of interest, busy schedule of work, most of them were not aware of extension activities and the male members did not permit them to attend, instead the male members only might had participated in the extension activities. The findings are in line with the findings of Raghavendra (2002), Chethana (2005) and Sangappa (2012).

\section{Social participation}

It could be inferred from the Table 9 that majority $(59.16 \%)$ of the respondents had low social participation followed by medium $(22.50 \%)$ and high $(18.34 \%)$ level of social participation. The possible reasons for this might be the fact that, normally women hesitate to participate, because of the male member's presence. Further women, most of the times are busy with household work and income generating activities. These findings are in line with the findings of Bharathi (2005) and Sowjanya (2007).

\section{Mass media exposure}

An examination of Table 10 revealed that 39.67 per cent of the respondents belonged to low mass media exposure followed by medium $(37.50 \%)$ and high $(23.33 \%)$ level of mass media exposure. Mass media are known for their accuracy, consistency, security, timeliness, completeness, conciseness, reliability and value-addition. Majority of respondents had low mass media exposure which might be due to their lack of interest and inconvenient timings to attend to this media. These findings are in 
agreement with findings of Bevinahalli (2005) and Sangappa (2012).

\section{Cosmopoliteness}

Observation at Table 11(a) brought to the notice that 35.83 per cent and 35.00 per cent of the women SHG members had high and medium level of cosmopoliteness respectively, followed by low level $(29.17 \%)$. The reason for having high cosmopoliteness is that due to their SHG related work and personal / domestic work at least weekly once they had to visit to the nearest town. These findings are in agreement with findings of Raghavendra (2002).

\section{Purpose of visit to nearest town}

Data in the Table 11(b) reveals the purpose of visit to the nearest town and it was ranked based on the frequency and percentage as given below, all related to SHG activities (I), personnel or domestic (II) and entertainment (III).The reason for this may be due to weekly once sandy day in the nearest town. So they need to procure inputs for their income generating activity, purchase domestic and personal daily needs and also sell their products in the market.

\section{Risk willingness}

Results in Table 12 reveal that 35.83 per cent of the women SHG members had medium level of risk willingness, whereas 32.50 per cent and 31.67 per cent had low and high level of risk willingness respectively. This might be due to non-availability of resources, lack of knowledge and also lack of amenities to aspire for better options and also less forces from the external atmosphere. The findings are in line with Devalatha (2005), Narayanaswamy (2005) and Sowjanya (2007).

\section{Achievement motivation}

It could be noted from the Table 13 that 41.67 per cent of the respondents had medium level of achievement motivation followed by low
$(32.50 \%)$ and high (25.83\%) level of achievement motivation. It is clear from the above findings that beneficiaries had medium achievement motivation. This might have resulted in the adoption of various activities as subsidiary occupation under SHGs. These findings are in agreement with findings of Bevinahalli (2005) and Sangappa (2012).

\section{Management orientation}

A glance at the Table 14 indicated that 47.50 per cent of the respondents had medium level of management orientation followed by low $(29.17 \%)$ and high (23.33\%) level of management orientation. This may be due to their medium extension participation, mass media exposure and low social participation and educational level. These findings are in agreement with findings of Narayanaswamy (2005) and Vinayak Narayan Nayak (2014).

\section{Deferred gratification}

It could be noted from the Table 15 that 40.83 per cent of the respondents had medium level of deferred gratification followed by low $(35.00 \%)$ and high $(24.17 \%)$ level of deferred gratification. The possible reason could be that most of the respondents believe that future uncertainties can be managed today and thus, they showed willingness to prepare for future uncertainties. The findings are in contrast with the findings of Anitha (2004).

Self Help Groups, as micro financial institutions emerged as an impetus for community action. It is an informal supplementary credit delivery mechanism by lending at group level. There are some studies on SHGs and its impact. Since, women SHGs are important as they are influencing rural people with respect to their income, employment, savings, investment and empowerment. The findings of this investigation hasl provided basis for planning future strategies or change in the current / existing system. The results of the study are of immense use to the financial institutions and the policy makers. 


\section{Acknowledgement}

I am overwhelmed with gratitude to the various SHG members for their valuable inputs. I also thank all the staff of the department of Agricultural extension, UAS, GKVK, Bangalore for their support and guidance.

\section{References}

Anitha, B., 2004, A study on entrepreneurial behavior and market participation of farm women in Bangalore Rural district of Karnataka. M.Sc. (Agri.) Thesis, Univ. Agri. Sci., Bangalore.

Arunkumar, T. D., 2004, Profile of SHGs and their contribution for livestock development in Karnataka. M. Sc. (Agri.) Thesis (Unpub.), Univ. Agric. Sci., Dharwad, Karnataka

Banerjee, G. D., 2002, Evaluation study on selfhelp group, Financing Agriculture - In house. J. Agric. Finan. Corp. Ltd., 34(2):38

Bevenahalli, A., 2005, A critical analysis of swa-shakti programme in Karnataka. $M$. Sc. (Agri.) Thesis, Univ. Agric. Sci., Dharwad, Karnataka.

Bharathi, R. A., 2005, Assessment of entrepreneurial activities promoted under NATP on empowerment of women in agriculture. M. Sc. (Agri.) Thesis (Unpub.), Univ. Agric. Sci., Dharwad, Karnataka.

Chethana, M.P., 2005, Impact of stree Shakti programme on farm women in Tumkur District. M.Sc.(Agri) Thesis (Unpublished), Univ. Agric. Sci., Banglore.

Devalatha, C. M., 2005, Profile study of women SHGs in Gadag district of northKarnataka. M. Sc. (Agri.) Thesis
(Unpub.), Univ. Agric. Sci., Dharwad, Karnataka.

Narayanaswamy, B., 2005, Performance of selfhelp groups in Karnataka - An analysis. Ph.D. Thesis, (Unpub.), University of Agricultural Sciences, Bangalore

Prasad, C.H., 1998, Implementation processes of women development programme (IFAD)-An experimental model. J. Rural Devp., 17(4): 779-791.

Purshotham, P., Laxminarayana, S. and Ramaiah T.G., 2010, Institutional credit to scheduled tribes SHG members: A process evaluation of SHG-bank linkage in three districts of Andhra Pradesh. J. of Rural Devt., 29 (1) pp. 1-15.

Raghavendra, H.G 2002, Comparative study on performance of women SHGs organized by two NGOs in Kolar District. M. Sc. (Agri.) Thesis (Unpub.), University of Agricultural Sciences, Bangalore

Rangi, P.S., Sidhu, M. S. and Harjit Singh, 2002, Economic empowerment of rural women through self help groups: A case study of Fategarh Sahib district (Punjab). Man and Devt., 24 (3) : 65-78.

Sangappa, 2012, Performance of gender specific self help groups in Bidar district of Karnataka: a comparative analysis. M.Sc. (Agri.) Thesis (Unpub.), Univ. Agri. Sci., Bengaluru.

Sowjanya, 2007, A comparative analysis of successful and unsuccessful self-help groups in Gadag district of Karnataka. M.Sc. (Agri.) Thesis (Unpub.), Uni. Agric. Sci. Dharwad.

Vinayak Narayan Nayak, (2014), A study on knowledge, adoption and economic performance of arecanut growers in north Kanara district of Karnataka. M.Sc. (Agri.) Thesis, (Unpub.), Univ. Agric. Sci., Bengaluru.

\section{How to cite this article:}

Asha, K., D. Nanjappa, M.B. Shanabhoga and Shivani Dechamma. 2018. Socio economic and Psychological Profile of Members of Self Help Groups in Ramanagara District of Karnataka, India. Int.J.Curr.Microbiol.App.Sci. 7(09): 3438-3446. doi: https://doi.org/10.20546/ijcmas.2018.709.426 